\title{
Adopsi IFRS dan Pengaruhnya Terhadap Manajemen Laba Akrual dan Manajemen Laba Riil Pada Perusahaan Manufaktur Di Bursa Efek Indonesia
}

\author{
Ismawati ${ }^{1}$, Rita Yuliana 2, Yuni Rimawati ${ }^{3}$ \\ Fakultas Ekonomi dan Bisnis \\ Universitas Trunojoyo Madura \\ Jl. Raya telang PO.BOX 2 Kamal, Bangkalan-Madura
}

\section{A R T I C L E I N F O}

Article history:

Received 2 Juni 2018

Revised 10 Juni 2018

Accepted 15 Juni 2018

\section{Keywords:}

Adoption of IFRS, Accrual Earnings Management, Real Earnings

Management

\begin{abstract}
A B S T R A C T
This study aims to provide empirical evidence on adoption of IFRS and the effect to accrual earnings management and real earnings management. This study used manufacturing firm data which is listing on Indonesia Stock

Exchange in 2010-2013 and there are 63 firm used as sample. This study used secondary data. 2010 and 2011's financial statement used to test descriptive statistic at the beginning stage adoption of IFRS. 2012 and 2013's financial statement used to test descriptive statistic at the advance stage adoption of IFRS. The technique of data analysis in this study using multiple linear regression analysis.

The result of this study find empirical evidence that IFRS adoption has negative influence to accrual earnings management. This finding confirmation the result of descriptive statistic that accruals earnings management stage descend at the advance stage adoption of IFRS compared to the beginning stage adoption of IFRS. IFRS adoption doesn't have influence to real earnings management through proxy as operation cash flow, production cost, and descretioner cost after firm adopted IFRS at the beginning stage and also at the advance stage adoption of IFRS.
\end{abstract}

\begin{abstract}
A B S T R A K
Penelitian ini bertujuan untuk memberikan bukti empiris mengenai adopsi IFRS dan pengaruhnya terhadap manajemen laba akrual dan manajemen riil. Penelitian ini menggunakan data perusahaan manufaktur yang listing di Bursa Efek Indonesia tahun 2010-2013 dan diperoleh sampel sebanyak 63 perusahaan dengan menggunakan metode purposive sampling. Data yang digunakan merupakan data sekunder. Laporan keuangan perusahaan manufaktur tahun 2010 dan tahun 2011 digunakan untuk menguji statistik deskriptif pada tahap awal adopsi IFRS. Laporan keuangan perusahaan manufaktur tahun 2012 dan tahun 2013 digunakan untuk menguji statistik deskriptif pada tahap lanjut adopsi IFRS. Teknik analisis data menggunakan analisis regresi linier berganda.

Hasil penelitian ini menemukan bukti empiris bahwa adopsi IFRS berpengruh negatif terhadap manajemen laba akrual. Temuan ini mengkonfirmasi hasil statistik deskriptif bahwa tingkat manajemen laba akrual menurun pada tahap lanjut adopsi IFRS dibandingkan pada tahap awal adopsi IFRS. Adopsi IFRS tidak berpengaruh terhadap manajemen laba riil melalui proksi arus kas operasi, biaya produksi, dan biaya diskresioner. Temuan ini belum bisa mengkonfirmasi terjadinya penurunan tingkat manajemen laba riil melalui proksi arus kas operasi, biaya produksi, dan biaya diskresioner setelah perusahaan mengadopsi IFRS pada tahap awal maupun pada tahap lanjut adopsi IFRS
\end{abstract}

\section{INTRODUCTION}

Praktik akuntansi di setiap negara berbedabeda karena adanya pengaruh lingkungan, ekonomi, sosial, dan politik di setiap negara.
Pada era globalisasi ini semua perusahaan dituntut untuk mempersiapkan, dan mengadopsi Standar Akuntansi Keuangan yang berlaku internasional, dengan tujuan Standar Akuntansi Keuangan yang

* Corresponding author, email address: ${ }^{1}$ ismawatismail21@gmail.com, ${ }^{2}$ albasta2011@gmail.com, ${ }^{3}$ rimawati.unieq@gmail.com 
berlaku internasional dapat memberikan pedoman bagaimana cara menyusun laporan keuangan yang baik dan berkualitas sesuai dengan standar yang berlaku. Menurut Qomariah (2013) standar akuntansi yang berkualitas sangat penting dalam menyusun dan menyajikan laporan keuangan karena akan menghasilkan informasi keuangan yang akurat dan dapat dipercaya oleh pengguna laporan keuangan baik pihak internal maupun pihak eksternal, sehingga dapat dijadikan acuan sebagai pengambilan keputusan.

Standar Akuntansi Keuangan yang berlaku internasional atau dikenal dengan International Financial Reporting Standards (IFRS) bertujuan untuk memudahkan rekonsiliasi bisnis dalam lintas negara. Salah satu alasan Indonesia menerapkan IFRS adalah karena Indonesia sudah memiliki komitmen dalam kesepakatan dengan Negaranegara G20 dan IFRS merupakan pedoman penyusunan laporan keuangan yang diterima secara global (Utami dkk, 2016).

Penerapan IFRS diklaim akan memberikan manfaat bagi peningkatan kualitas laporan keuangan dan juga memberikan dampak terhadap pengguna laporan keuangan. Karena nantinya akan semakin sedikit dalam pemilihan metodemetode akuntansi yang akan diterapkan dan dapat meminimalisir kecurangan-kecurangan yang saat ini banyak terjadi di dalam dunia praktik akuntansi (Prihadi, 2011:4 dalam Rohaeni dan Aryati, 2012).

Pihak manajemen dituntut untuk membuat laporan keuangan sesuai dengan kondisi perusahaan yang sebenarnya. Namun, yang terjadi di lapangan manajemen seringkali berbuat dan melakukan tindakan kecurangan dalam hal menentukan laba perusahaaan untuk mencapai target laba yang diingankan agar laporan keuangan yang dihasilkan perusahaan dapat terlihat baik dan sehat oleh pengguna informasi keuangan. Hal tersebut dapat menyebabkan laporan keuangan yang dibuat oleh manajer secara tidak langsung dapat menyesatkan pengguna informasi keuangan (stakeholders) mengenai kinerja ekonomi perusahaan dalam hal pengambilan keputusan. Tindakan kecurangan yang dilakukan oleh manajer semacam ini dinamakan sebagai manajemen laba atau earnings management (Iranto, 2014).

Manajemen laba dapat dilakukan oleh manajer melalui dua cara: Pertama, manajer melakukan tindakan manajemen laba melalui discretionary accruals, (Utami dkk, 2016). Kedua, manajer juga dapat melakukan tindakan manajemen laba riil melalui aktivitas operasi perusahaan. Manajemen laba riil dapat dilakukan melalui aktivitas arus kas operasi, biaya produksi, dan biaya diskresioner (Roychowdhury, 2006).

Kualitas laporan keuangan dapat dilihat dari perilaku manajemen laba yang dilakukan, semakin rendah tingkat manajemen laba dalam suatu laporan keuangan, maka semakin berkuliatas laporan keuangan tersebut. Dengan demikian, setelah diberlakukannya IFRS secara full adoption pada tahun 2012, diharapkan dapat meningkatkan kualitas informasi laporan keuangan yang ditandai dengan menurunnya tingkat manajemen laba karena penerapan IFRS dengan pendekatan principle based dapat membatasi tindakan oportunistik manajemen dalam melakukan praktik manajemen laba dan penggunaan fair value lebih dapat merefleksikan kondisi ekonomik perusahaan yang sesungguhnya (Barth, et al., 2008).

Beberapa penelitian telah dilakukan mengenai adopsi IFRS terhadap manajemen laba akrual maupun manajemen laba riil dan terdapat inkonsistensi hasil, Barth, et al., (2008) menemukan bukti empiris bahwa setelah dikenalkannya IFRS, tingkat manajemen laba menjadi lebih rendah, relevansi nilai menjadi lebih tinggi dan pengakuan kerugian menjadi semakin tepat waktu, dibandingkan dengan masa sebelum transisi dimana akuntansi masih berdasarkan lokal GAAP. Qomariah (2013) menemukan bukti empiris bahwa konvergensi IFRS berpengaruh negatif terhadap tindakan manajemen laba melalui discretionary accruals. Lippens (2008) memberikan bukti empiris bahwa penerapan IFRS mempunyai pengaruh positif terhadap manajemen laba riil melalui aktifitas manipulasi pengelolaan penjualan dan peningkatan produksi.

Hasil penelitian yang berbeda ditemukan oleh Rudra dan Bhattacharjee (2012) menemukan bukti empiris bahwa manajemen laba melalui discretionary accruals meningkat secara signifikan dengan adanya adopsi IFRS. Doukakis (2014) menunjukkan bukti empiris bahwa, adopsi wajib IFRS di Eropa tidak berpengaruh terhadap manajemen laba riil atau manajemen laba berbasis akrual. Limanto dan Fanani (2014) menunjukkan bukti empiris bahwa adopsi IFRS di Indonesia tidak signifikan terhadap manajemen laba melalui discretionary accruals.

Penelitian ini termotivasi dari beberapa penelitian sebelumnya. Pembeda penelitian ini dengan penelitian sebelumnya yaitu penelitian ini dilakukan untuk menguji kembali mengenai pengaruh adopsi IFRS terhadap manajemen laba. Penelitian ini menambah variabel dependen menjadi ma- 
najemen laba akrual dan manajemen laba riil. Dalam penelitian ini, peneliti menguji dua tahap periode adopsi IFRS, yaitu; pertama, tahun 2010 dan tahun 2011 digunakan untuk menguji statistik deskriptif pada tahap awal adopsi IFRS sebelum full adoption. Kedua, tahun 2012 dan tahun 2013 digunakan untuk menguji statistik deskriptif pada tahap lanjut adopsi IFRS setelah full adoption.

Berdasarkan uraian latar belakang diatas maka rumusan masalah dalam penelitian ini adalah: (1) Apakah adopsi IFRS berpengaruh terhadap manajemen laba akrual pada perusahaan manufaktur di Bursa Efek Indonesia? (2) Apakah adopsi IFRS berpengaruh terhadap manajemen laba riil melalui proksi arus kas operasi pada perusahaan manufaktur di Bursa Efek Indonesia? (3) Apakah adopsi IFRS berpengaruh terhadap manajemen laba riil melalui proksi biaya produksi pada perusahaan manufaktur di Bursa Efek Indonesia? (4) Apakah adopsi IFRS berpengaruh terhadap manajemen laba riil melalui proksi biaya diskresioner pada perusahaan manufaktur di Bursa Efek Indonesia?

\section{THEORETICAL FRAMEWORK AND HYPO- THESES}

Teori Sinyal (Signalling Theory)

Menurut Brigham dan Houston (2001:36), signal adalah suatu tindakan yang diambil manajemen perusahaan yang memberi petunjuk bagi investor tentang bagaimana manajemen memandang prospek persahaan. Teori sinyal didasarkan pada asumsi bahwa adanya asimetri informasi antara manajemen dan pihak-pihak yang berkepentingan dengan informasi yang dibutuhkan. Pemberian sinyal yang dilakukan oleh manajemen merupakan cara untuk mengurangi dari asimetri informasi yang terjadi.

Terdapat dua tujuan yang memotiviasi manajemen untuk melakukan manajemen laba, yaitu tujuan oportunistik dan tujuan informasi (signaling) investor (Agmarina, 2011). Armando dan Farahmita (2012) menambahkan bahwa manajemen laba melalui aktivitas riil bukanlah manajemen laba yang bersifat oportunistik, perusahaan di masa depan dan berfungsi sebagai signaling. Pada motivasi signaling, manajemen melakukan manajemen laba dalam rangka memberikan sinyal kemakmuran kepada pemegang saham.

\section{Teori Keagenan (Agency Theory)}

Menurut Jensen \& Meckling (1976), hubungan keagenan merupakan sebuah kontrak antara agent dengan principal. Prinsip utama dari teori keagenan adalah menjelaskan adanya hubungan kerja antara satu pihak yang disebut agent, yaitu manajemen perusahaan dan pihak lain yang disebut principal, yaitu pemegang saham yang berkepentingan atas kepemilikannya terhadap perusahaan.

Teori keagenan menyatakan bahwa praktik manajemen laba dipengaruhi oleh adanya konflik kepentingan antara agent dengan principal yang timbul ketika setiap pihak berusaha untuk mencapai atau mempertahankan tingkat kemakmuran yang dikehendakinya (Iranto, 2014).

\section{Manajemen Laba}

Menurut Sulistyanto (2008:48) manajemen laba adalah upaya manajer perusahaan untuk mengintervensi atau mempengaruhi informasiinformasi dalam laporan keuangan dengan tujuan untuk mengelabui stakeholder yang ingin mengetahui kinerja dan kondisi perusahaan. Sementara itu, Scott (2006) mendefinisikan earnings management sebagai suatu tindakan manajer yang memilih kebijakan akuntansi untuk mencapai beberapa tujuan yang spesifik.

\section{Manajemen Laba Akrual}

Manajemen laba akrual adalah tindakan yang dilakukan manajer pada akhir periode melalui discretionary accruals, ketika manajer mengetahui berapa tingkat laba yang harus dimanipulasi agar sesuai dengan target laba yang diinginkan. Namun, manajemen laba akrual ini dapat dengan mudah terdeteksi kecuranganya oleh auditor, investor ataupun badan pemerintah sehingga akan berdampak pada harga saham bahkan menyebabkan kebangkrutan atau kasus hukum pada perusahaan tersebut (Utami dkk, 2016).

\section{Manajemen Laba Riil}

Manajemen laba riil adalah tindakan yang dilakukan oleh manajer untuk memenuhi target laba yang diinginkan dan menghindari kerugian melalui aktivitas operasional perusahaan selama periode siklus akuntansi (Utami dkk, 2016). Kegiatan manajemen laba riil dimulai dari aktivitas operasional perusahaan, yang dimotivasi oleh manajer yang berkeinginan untuk mengelabui bahkan menyesatkan stakeholder yang ingin mengetahui kinerja dan kondisi dari perusahaan tersebut.

Menurut Roychowdhury (2006) dalam Sulistiawan, dkk (2011:76-77) menyatakan bahwa praktik manajemen laba riil dapat dilakukan 
dengan menggunakan tiga metode sebagai berikut:

1) Manipulasi penjualan atau meningkatkan penjualan secara tidak wajar (sales manipulation). Cara ini dilakukan dengan menawarkan diskon harga atau syarat kredit yang ringan. Akibatnya, manajemen perusahaan dapat meningkatkan penjualan selama tahun berjalan sehingga akan meningkatkan nilai laba kotornya. Namun, peningkatan volume penjualan ini akan hilang ketika harga jual kembali ke harga awal.

2) Mengurangi pengeluaran diskresioner. Pengeluaran diskresioner seperti biaya riset dan pengembangan, biaya iklan, dan biaya pemeliharaan dibebankan pada periode terjadinya. Dengan begitu perusahaan dapat mengurangi biaya yang dilaporkan dan meningkatkan laba dengan mengurangi biaya diskresioner. Pada proses pergantian direksi atau pimpinan perusahaan, pengelola lama cenderung menunda atau mengurangi pengeluaran diskresioner untuk mendapatkan bonus dari penyajian laba yang besar pada tahunnya.

3) Produksi yang berlebihan (overproduction). Agar laba naik, manajer memproduksi lebih banyak persediaan dari yang sewajarnya untuk memenuhi permintaan. Dengan tingkat produksi yang lebih tinggi, biaya overhead tetap per unit makin kecil sehingga biaya per unitnya akan turun. Hal ini membuat biaya barang terjual lebih rendah sehingga perusahaan mendapat keuntungan operasi yang lebih baik. Namun akibatnya, persediaan barang perusahaan di pasar menjadi besar dan akan berimbas pada permintaan barang pada masa mendatang.

\section{International Financial Reporting Standard (IFRS)}

International Financial Reporting Standard (IFRS) merupakan standar, interpretasi dan kerangka kerja dalam rangka penyusunan dan penyajian laporan keuangan yang disusun oleh IASC (International Accounting Standards Committee), organisasi pendahulu dari IASB (International Accounting Standards Board).

Menurut Ahmar, dkk (2016) tiga hal utama yang membedakan antara IFRS dengan aturan sebelum IFRS (GAAP atau PSAK sebelum konvergensi ke IFRS). Tiga hal tersebut adalah:

1) IFRS merupakan standar yang berbasis prinsip (principle based) sedangkan standar sebelumnya berbasis aturan (rules based). Principle based berarti pengaturan pada tingkat prinsip akan meliputi segala hal dibawahnya.

2) IFRS lebih condong pada penggunaan konsep fair value (nilai wajar) sedangkan aturan sebelumnya lebih condong pada penggunaan konsep historical cost. Menurut lampiran Keputusan Ketua Bapepam dan LK No: KEP-347/BL/2012 nilai wajar adalah nilai dimana suatu aset dipertukarkan atau liabilitas diselesaikan antar pihak yang memahami atau berkeinginan untuk melakukan transaksi wajar (arms's length transactions).

3) IFRS mengharuskan pengungkapan yang lebih rinci dan detail tentang resiko baik kualitatif maupun kuantitatif dari pada standar sebelumnya. Hal mengenai pengungkapan ini juga diatur di bagian $\mathrm{C}$ Keputusan Ketua Bapepam dan LK No: KEP-347/BL/2012.

\section{Adopsi IFRS di Indonesia}

Lembaga profesi akuntan IAI (Ikatan Akuntan Indonesia) menetapkan bahwa Indonesia melakukan adopsi penuh IFRS (Full Adoption) pada 1 Januari 2012. Penerapan ini bertujuan agar daya informasi laporan keuangan dapat terus meningkat sehingga laporan keuangan dapat semakin mudah dipahami dan dapat dengan mudah digunakan baik bagi penyusun laporan keuangan, auditor, maupun pengguna laporan keuangan.

Tahapan yang dilakukan Indonesia dalam melakukan adopsi IFRS adalah (Iranto, 2014):

1. Tahap Adopsi (2008 - 2010)

a. Adopsi seluruh IFRS ke PSAK

b. Persiapan infrastruktur yang diperlukan

c. Evaluasi dan kelola dampak adopsi terhadap PSAK yang berlaku

2. Tahap persiapan Akhir (2011)

a. Penyelesaian infrastruktur yang diperlukan

b. Penerapan secara bertahap beberapa PSAK berbasis IFRS

3. Tahap Implementasi (2012)

a. Penerapan PSAK berbasis IFRS secara bertahap

b. Evaluasi dampak penerapan PSAK secara komprehensif 


\section{Kerangka Pemikiran}

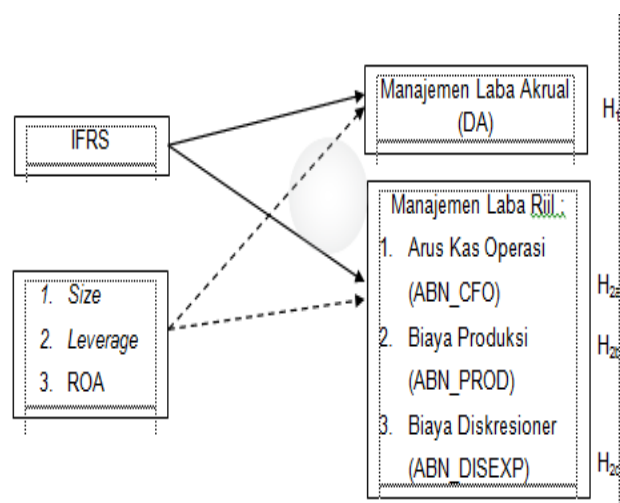

\section{Pengembangan Hipotesis}

\section{Pengaruh Adopsi Manajemen Laba Akrual}

Terdapat argumentasi bahwa penerapan IFRS dapat meningkatkan kualitas informasi akuntansi karena penggunaan fair value lebih dapat merefleksikan kondisi ekonomik perusahaan. Selain itu, penerapan IFRS dengan pendekatan principle based juga dapat membatasi tindakan oportunistik manajemen (Barth, et al., 2008).

Barth, et al., (2008) menemukan bukti dari penelitiannya bahwa setelah dikenalkannya IFRS, tingkat manajemen laba menjadi lebih rendah, relevansi nilai menjadi lebih tinggi, dan pengakuan kerugian menjadi semakin tepat waktu, dibandingkan dengan masa sebelum transisi di mana akuntansi masih berdasarkan lokal GAAP. Ismail, et al., (2013) hasil penelitiannya menunjukkan adanya penurunan manajemen laba melalui discretionary accruals setelah perusahaan menerapkan standar akuntansi berbasis IFRS. Qomariah (2013) hasilnya menemukan bukti bahwa konvergensi IFRS berpengaruh negatif terhadap tindakan manajemen laba melalui discretionary accruals.

Berdasarkan uraian diatas, peneliti menyusun hipotesis sebagai berikut:

H1 : Adopsi IFRS berpengaruh negatif terhadap Manajemen Laba Akrual

\section{Pengaruh adopsi IFRS terhadap Manajemen Laba Riil Melalui Proksi Arus Kas Operasi, Biaya Produksi, dan Biaya Diskresioner \\ Manajemen laba riil biasanya sering dilakukan} oleh pihak manajer melalui aktivitas arus kas operasi, biaya produksi, dan biaya diskresioner (Roychowdhury, 2006). Manajemen laba riil melalui aktivitas arus kas operasi dapat dilakukan dengan cara manajemen penjualan yaitu memberikan potongan harga besar-besaran, bunga kredit yang rendah atau dengan produksi besarbesaran supaya harga pokok penjualan rendah sehingga margin operasi tinggi. Semakin rendah nilai arus kas operasi abnormal maka semakin tinggi laba yang ilaporkan (Armando dan Farahmita, 2012).

Manjemen laba riil melalui biaya produksi dapat dilakukan dengan cara overproduction. Manajer perusahaan melakukan produksi barang lebih banyak melebihi permintaan pasar, karena produksi dalam skala besar dapat menyebabkan fixed cost per unit lebih rendah dan harga pokok penjualan menurun. Harga pokok penjualan menurun dapat menyebabkan margin operasi tinggi dan arus kas operasi menjadi rendah daripada tingkat penjualan normal. Hal ini yang menyebabkan dapat meningkatnya laba operasi perusahaan (Handayani, 2014).

Manajemen laba riil melalui reduksi biaya diskresioner biasa dilakukan oleh manajer dengan cara mengurangi biaya iklan, biaya riset dan pengembangan, biaya penjualan, dan biaya administrasi dan umum. Perusahaan dapat mengurangi biaya diskresioner untuk meningkatkan laba perusahaan. Hal tersebut dilakukan oleh manajer, ketika pengeluaran tersebut belum dikonversi menjadi pendapatan dan laba. Apabila pengeluaran biaya diskresioner dalam bentuk kas, maka pengurangan biaya diskresioner akan berdampak pada arus kas keluar sehingga berdampak positif pada arus kas operasi abnormal periode saat ini dan kemungkinan menyebabkan arus kas yang lebih rendah pada periode berikutnya (Roychowdhury, 2006).

Penelitian yang dilakukan Lippens (2008) di Eropa menunjukkan bahwa penerapan IFRS mempunyai pengaruh positif tehadap manajemen laba riil melalui aktivitas manipulasi pengelolaan penjualan dan peningkatan produksi. Penelitian yang dilakukan oleh Doukakis (2014) menunjukkan bukti empiris bahwa, adopsi wajib IFRS tidak berpengaruh signifikan terhadap praktik manajemen laba riil atau manajemen berbasis akrual. Penelitian lain yang dilakukan oleh Ahmar, dkk (2016) menunjukkan bahwa, ada perbedaan yang signifikan perilaku/nilai manajemen laba riil dengan pendekatan beban diskresioner dan biaya produksi, sedangkan manajemen laba riil dengan pendekatan arus kas operasi tidak terbukti signifikan.

Terdapat banyak penelitian mengenai Adopsi 
IFRS terhadap manajemen laba rill namun terdapat inkonsistensi hasil dari penelitian terdahulu. Oleh karena itu, jika manajemen laba akrual menurun setelah adopsi IFRS, kemungkinan tingkat manajemen laba riil akan meningkat.

Berdasarkan uraian diatas, peneliti menyusun hipotesis sebagai berikut:

$\mathrm{H2a}$ : Adopsi IFRS berpengaruh positif terhadap manajemen laba riil melalui proksi arus kas operasi

$\mathrm{H} 2 \mathrm{~b}$ : Adopsi IFRS berpengaruh positif terhadap manajemen laba riil melalui proksi biaya produksi

H2c : Adopsi IFRS berpengaruh positif terhadap manajemen laba riil melalui proksi biaya diskresioner

\section{METODE PENELITIAN}

\section{Jenis Penelitian}

Jenis penelitian yang digunakan dalam penelitian ini adalah penelitian dengan pendekatan kuantitatif.

\section{Objek Penelitian}

Objek penelitian dalam penelitian ini adalah perusahaan manufaktur yang listing di Bursa Efek Indonesia tahun 2010-2013.

\section{Populasi dan Sampel}

Populasi dalam penelitian ini adalah seluruh perusahaan manufaktur yang listing di Bursa Efek Indonesia tahun 2010-2013. Teknik pengambilan sampel yang digunakan dalam penelitian ini adalah purposive sampling yaitu pengambilan sampel berdasarkan kriteria. Kriteria yang digunakan sebagai berikut:

1) Perusahaan manufaktur yang konsisten listing di Bursa Efek Indonesia tahun 2010-2013 dan tidak keluar (delisting) selama periode pengamatan tahun 2010-2013.

2) Perusahaan manufaktur yang mempublikasikan laporan keuangan periode pengamatan tahun 2010-2013

3) Memiliki data lengkap terkait dengan variabel yang digunakan.

4) Perusahaan manufaktur yang menerbitkan laporan keuangan per 31 Desember dari tahun 2010-2013 dalam satuan mata uang rupiah.

\section{Jenis dan Sumber Data}

Data yang digunakan dalam penelitian ini adalah datas ekunder. Sumber data diperoleh dari situs resmi Bursa Efek Indonesia dan laman resmi dari masing-masing perusahaan.

\section{Definisi Operasional Variabel \\ Variabel Independen}

Variabel independen dalam penelitian ini adalah adopsi IFRS. Pengukuran variabel ini menggunakan variabel dummy, yaitu nilai 0 untuk perusahaan yang belum mengadopsi IFRS secara full adoption dan nilai 1 untuk perusahaan yang sudah mengadopsi IFRS secara full adoption.

Variabel Dependen

Manajemen Laba Akrual (DA)

Pada penelitian ini manajemen laba akrual menggunakan proksi discretionary accruals sesuai dengan Modified Jones Model (Dechow et al.1995). Tahapan perhitungan untuk mendapatkan nilai discretionary accruals sebagai berikut (Dechow et al, 1995):

1. Menetukan nilai total akrual

\section{TAit $=$ Nit - CFOit}

2. Nilai total akrual (TA) yang diestimasi dengan persamaan regresi OLS sebagai berikut (Dechow et al, 1995):

TAit/Ait-1 $=\beta 1(1 /$ Ait-1 $)+\beta 2(\Delta$ Revit/Ait-1 $)+$ $\beta 3$ (PPEit/Ait-1) + cit

3. Dengan menggunakan koefisien regresi diatas nilai non discretionary accruals (NDA) dapat dihitung dengan rumus (Dechow et al, 1995):

NDAit $=\beta 1(1 /$ Ait-1 $)+\beta 2(\Delta$ Revit/Ait-1 $\Delta$ Recit/Ait-1 ) $+\beta 3$ (PPEit/Ait-1)

4. Selanjutnya, discretionary accruals (DA) dapat dihitung sebagai berikut (Dechow et al,1995):

\section{DAit $=($ TAit/Ait-1) - NDAit}

Keterangan:

Tait $=$ Total akrual perusahaan $\mathrm{i}$ pada periode ke $\mathrm{t}$

Nit $=$ Laba bersih perusahaan i pada periode ke $t$

$\mathrm{CFOit}=$ Arus kas operasi perusahaan $\mathrm{i}$ pada periode ke $t$

Ait-1 = Total asset perusahaan i pada periode ke $\mathrm{t}$ $-1$

$\Delta$ Revit $=$ Perubahan pendapatan perusahaan i pada periode ke $t$

PPEit $=$ Asset tetap $($ Property, plant, and equipment $)$ perusahaan I pada periode ke $t$

NDAit $=$ Non discretionary accruals perusahaan i pada periode ke $t$

$\Delta$ Recit $=$ Perubahan piutang perusahaan i pada periode ke $\mathrm{t}$

Dait $=$ Discretionarry accruals

$\beta 1-\beta 3=$ Koefisien regresi

$\varepsilon \quad=$ Error term perusahaan i pada periode $\mathrm{t}$

\section{Manajemen Laba Riil}

Manajemen laba riil diukur dengan model yang dikembangkan oleh Roychowdhury (2006) dengan menghitung tiga proksi yaitu: 
a. Manajemen Laba Riil melalui

Arus Kas Operasi (ABN_CFO) Roychowdhury (2006) menggunakan model regresi untuk arus kas operasi normal sebagai berikut:

CFOt/At-1 $=\alpha 0+\alpha 1(1 /$ At-1) $+\beta 1($ St/At-1) + $\beta 2(\Delta S t / A t-1)+\varepsilon t$

Sehingga, arus kas operasi abnormal (ABN_CFO) diperoleh dari rumus;

ABN_CFO = CFOt - CFOt/At-1

Keterangan:

$\mathrm{CFOt}=$ Arus kas kegiatan operasi pada tahun $\mathrm{t}$

At-1 = Total asset pada tahun $\mathrm{t}-1$

St $=$ Penjualan pada tahun $\mathrm{t}$

$\Delta S t \quad=$ Penjualan pada tahun $t$ dikurangi penjualan pada tahun $\mathrm{t}-1$

et $\quad=$ Error term pada tahun $\mathrm{t}$

b. Manajemen Laba Riil melalui Biaya Produksi (ABN_PROD) Roychowdhury (2006) menggunakan model regresi untuk biaya produksi normal sebagai

berikut:

PRODt/At-1 $=\alpha 0+\alpha 1(1 /$ At-1) $+\beta 1($ St/At-1) + $\beta 2(\Delta$ St/At-1) $+\beta 3(\Delta$ St-1/At-1) $+\varepsilon t$

Sehingga, biaya produksi abnormal (ABN_PROD) diperoleh dari rumus:

ABN_PROD = PRODt - PRODt/At-1

Keterangan:

PROD $\mathrm{t}=$ Biaya produksi pada tahun $\mathrm{t}$, dimana

PRODt $=$ COGSt $+\Delta \mathrm{INVt}$

At-1 = Total asset pada tahun $\mathrm{t}-1$

St $\quad=$ Penjualan pada tahun $\mathrm{t}$

$\Delta S t=$ Penjualan pada tahun $\mathrm{t}$ dikurangi penjualan pada tahun $\mathrm{t}-1$

$\Delta$ St-1 = Perubahan penjualan pada tahun $\mathrm{t}-1$

et $\quad=$ Error term pada tahun $\mathrm{t}$

c. Manajemen Laba Riil melalui Biaya

Diskresioner (ABN_DISEXP)

Roychowdhury (2006) menggunakan model regresi untuk biaya diskresioner normal sebagai

berikut:

DISEXPt/At-1 $=\alpha 0+\alpha 1(1 /$ At-1) $+\beta($ St/At-1) $+\varepsilon t$

Sehingga, biaya diskresioner abnormal (ABN_DISEXP) diperoleh dari rumus;

ABN_DISEXP = DISEXPt - DISEXPt/At-1

Keterangan:

DISEXPt $=$ Biaya diskresioner pada tahun $\mathrm{t}$

At- $\quad=$ Total asset pada tahun $\mathrm{t}-1$

St $\quad=$ Penjualan pada tahun $\mathrm{t}$

et $\quad=$ Error term pada tahun $\mathrm{t}$

\section{Variabel Kontrol}

Penelitian ini menggunakan tiga variabel kontrol yaitu;

1. Size (Ukuran Perusahaan)
Size $=$ Ln.Total Aset

2. Leverage

$$
\text { LEV }=\frac{\text { Total Hutang }}{\text { Total Aset }}
$$

3. ROA (Return on Asset)

ROA $=\frac{\text { EAT }(\text { Laba bersih setelah Pajak })}{\text { Total Asset }(\text { Total Aset })}$

Teknik Analisis Data

Analisis Statistik Deskriptif

Pengujian statistik deskriptif dalam penelitian ini terbagi menjadi dua yaitu: pertama, pengujian tahap awal adopsi IFRS tahun 2010-2011. Kedua, pengujian tahap lanjut adopsi IFRS tahun 20122013.

\section{Uji Asumsi Klasik}

Uji asumsi klasik yang akan digunakan dalam penelitian ini terdiri dari, uji normalitas, uji multikolinieritas, dan uji heteroskedastisitas.

\section{Pengujian Hipotesis}

Analisis Regresi Linier Berganda

Model persamaan regresi linier berganda untuk mengukur pengaruh adopsi IFRS terhadap manajemen laba akrual dan manajemen laba riil sebagai berikut:

Model 1 : Manajemen Laba Akrual

$\mathrm{DA}=\alpha+\beta 1$ IFRS $+\beta_{2}$ SIZE $+\beta 3 \mathrm{LEV}+\beta 4 \mathrm{ROA}$ $+\varepsilon$

Model 2 : Manajemen Laba Riil

$\mathrm{ABN} \_\mathrm{CFO}=\alpha+\beta 1 \mathrm{IFRS}+{ }^{\boldsymbol{\beta}} \mathbf{2} \mathrm{SIZE}+\boldsymbol{\beta} 3 \mathrm{LEV}+\boldsymbol{\beta} 4$ $\mathrm{ROA}+\varepsilon$

$\mathrm{ABN} \_\mathrm{PROD}=\alpha+\beta 1$ IFRS $+\boldsymbol{\beta}_{2}$ SIZE $+\beta 3 \mathrm{LEV}+$ $\beta 4 \mathrm{ROA}+\varepsilon$

ABN_DISEXP $=\alpha+\beta 1$ IFRS $+\beta_{2}$ SIZE $+\beta 3$ LEV $+\beta 4 \mathrm{ROA}+\varepsilon$

Keterangan :

$\mathrm{DA}=$ Variabel dependen manajemen laba akrual

ABN_CFO = Variabel dependen manajemen laba riil proksi arus kas operasi

ABN_PROD = Variabel dependen manajemen laba riil proksi biaya produksi

ABN_DISEXP = Variabel dependen manajemen laba riil proksi biaya diskresioner

IFRS $=$ Variabel independen adopsi IFRS (dummy 0 untuk perusahaan yang belum mengadopsi IFRS secara full adoption dan dummy 1 untuk perusahaan yang mengadopsi IFRS secara full adoption)

SIZE = Variabel kontrol logaritma natural total asset

LEV = Variabel kontrol leverage 


$$
\begin{array}{ll}
\mathrm{ROA} & =\text { Variabel kontrol Return on Asset } \\
\mathrm{\alpha} & =\text { Konstanta } \\
\beta 1-\beta 4 & =\text { Koefisien Regresi } \\
\varepsilon & =\text { Error }
\end{array}
$$

\begin{tabular}{|c|c|c|c|c|c|}
\hline & $\mathrm{Me}$ & Std. & tion. & Minimum & \\
\hline \multirow{2}{*}{ DA } & Tahap Awal & $\overline{126}$ & .061 & .102 & -.160 \\
\hline & Tahap Lanjut & 126 & .020 & .103 & -284 \\
\hline \multirow{3}{*}{ ABN_CFO } & Tahap Awal & 126 & .000 & .145 & -.429 \\
\hline & Tahap Lanjut & 126 & .000 & .153 & -.707 \\
\hline & Tahap Awal & 126 & -.002 & .378 & -.852 \\
\hline \multirow[t]{2}{*}{ ABN_PROD } & Tahap Lanjut & 126 & .000 & .247 & . .646 \\
\hline & Tahap Awal & 126 & .000 & .171 & .200 \\
\hline \multirow[t]{2}{*}{ ABN_DISEXP } & Tahap Lanjut & 126 & .000 & .189 & -.510 \\
\hline & Tahap Awal & 126 & 27.944 & 1.647 & 25.083 \\
\hline \multirow[t]{2}{*}{ SIZE } & Tahap Lanjut & 126 & 28.277 & 1.719 & 25.277 \\
\hline & Tahap Awal & 126 & .414 & .181 & .094 \\
\hline \multirow[t]{2}{*}{ LEV } & Tahap Lanjut & 126 & .418 & .182 & .037 \\
\hline & Tahap Awal & 126 & .113 & .092 & .000 \\
\hline ROA & Tahap Lanjut & 126 & .116 & .106 & .000 \\
\hline
\end{tabular}

\section{DATA ANALYSIS AND DISCUSSION Deskripsi Hasil Penelitian}

\section{Tabel 4.1}

\section{Uji Asumsi Klasik}

\section{Uji Normalitas}

Hasil uji normalitas dari model persamaan 1 (DA) diperoleh nilai kolmogorov smirnov sebesar 1,131 dengan nilai signifikan 0,155 yang artinya 0,155 $>0,05$ yaitu menunjukkan bahwa data dari model persamaan 1 berdistribusi secara normal. Model persamaan 2 (ABN_CFO) diperoleh nilai kolmogorov smirnov sebesar 0,994 dengan nilai signifikan 0,276 yang artinya $0,276>0,05$ yaitu menunjukkan bahwa data dari model persamaan 2 berdistribusi secara normal.

Model persamaan 3 (ABN_PROD) diperoleh nilai kolmogorov smirnov sebesar 1,956 dengan nilai signifikan 0,001 yang artinya $0,001<0,05$ yaitu menunjukkan bahwa data dari model persamaan 3 tidak berdistribusi secara normal. Model persamaan 4 (ABN_DISEXP) diperoleh nilai kolmogorov smirnov sebesar 2,643 dengan nilai signifikan 0,000 yang artinya 0,000 $<0,05$ yaitu menunjukkan bahwa data dari model persamaan 4 tidak berdistribusi secara normal.

\section{Uji Multikolinieritas}

Hasil uji multikolinieritas dari keempat model persamaan regresi yaitu, model persamaan 1 (DA), model persamaan 2 (ABN_CFO), model persamaan 3 (ABN_PROD), dan model persamaan 4 (ABN_DISEXP) menunjukkan nilai tolerance dari semua variabel menunjukkan nilai $>0,10$ dan nilai Variance Inflation Factor (VIF) dari semua variabel menunjukkan nilai < 10. Maka dari itu dapat disimpulkan bahwa tidak terjadi multikolinieritas diantara variabel IFRS, SIZE, LEV, dan ROA dari keempat model persamaan regresi.

\section{Uji Heteroskedastisitas}

Hasil uji heteroskedastisitas dari model persamaan 1 (DA) menunjukkan bahwa titik-titik menyebar secara acak di atas dan di bawah angka 0 pada sumbu $Y$ dan tidak membentuk pola tertentu. Sehingga dapat disimpulkan bahwa tidak terjadi heterokedastisitas pada model persamaan 1 (DA).

Model persamaan 2 (ABN_CFO) menunjukkan bahwa titik-titik menyebar secara acak di atas dan di bawah angka 0 pada sumbu $Y$ dan tidak membentuk pola tertentu. Sehingga dapat disimpulkan bahwa tidak terjadi heterokedastisitas pada model persamaan 2 (ABN_CFO). Model persamaan 3 (ABN_PROD) menunjukkan bahwa titik-titik tidak menyebar secara acak di atas dan di bawah angka 0 pada sumbu $\mathrm{Y}$ dan membentuk pola tertentu.

Sehingga dapat disimpulkan bahwa terjadi heterokedastisitas pada model persamaan 3 (ABN_PROD). Model persamaan 4 (ABN_DISEXP) menunjukkan bahwa titik-titik tidak menyebar secara acak di atas dan di bawah angka 0 pada sumbu $Y$ dan membentuk pola tertentu. Sehingga dapat disimpulkan bahwa terjadi heterokedastisitas pada model persamaan 4 (ABN_DISEXP).

\section{Pengujian Hipotesis \\ 1. Model Persamaan 1 (DA)}

Adjusted R Square sebesar 0,064 atau 6,4\%, hal ini berarti bahwa variabel manajemen laba akrual (DA) dapat dijelaskan oleh adopsi IFRS sebagai variabel independen dan SIZE, LEV, ROA sebagai variabel kontrol. Sisanya sebesar $93,6 \%$ variabel manajemen laba akrual (DA) dapat dijelaskan oleh variabel lain.

Nilai Fhitung sebesar 5,295 dengan tingkat signifikan 0,000 $(<0.01)$. Hal ini berarti bahwa variabel independen dan variabel kontrol secara bersama-sama berpengaruh secara signifikan terhadap variabel dependen yaitu manajemen laba akrual (DA).

Variabel kontrol SIZE mempunyai nilai thitung sebesar 0.591 dengan tingkat signifikan sebesar $0.555>0.01,0.05$, dan 0.1. Hal ini berarti bahwa variabel kontrol SIZE tidak berpengaruh terhadap manajemen laba akrual. Variabel kontrol LEV mempunyai nilai thitung sebesar 2.881 dengan tingkat signifikan sebesar $0.004<0.01$. Hal ini berarti bahwa variabel kontrol LEV berpengaruh terhadap bahwa variabel manajemen laba riil melalui proksi arus kas operasi (ABN_CFO) dapat dijelaskan oleh adopsi IFRS sebagai variabel independen dan SIZE, LEV, ROA sebagai variabel kontrol. Sisanya sebesar 53,1\% variabel manajemen 
laba riil melalui proksi arus kas operasi (ABN_CFO) dapat dijelaskan oleh variabel lain.

Nilai Fhitung sebesar 56,369 dengan tingkat signifikan 0,000 (<0.01). Hal ini berarti bahwa variabel independen dan variabel kontrol secara bersama-sama berpengaruh secara signifikan terhadap variabel dependen yaitu manajemen laba riil melalui proksi arus kas operasi (ABN_CFO).

Variabel kontrol SIZE mempunyai nilai thitung sebesar 1.330 dengan tingkat signifikan sebesar $0.185>0.01,0.05$ dan 0.1 . Hal ini berarti bahwa variabel kontrol SIZE tidak berpengaruh terhadap manajemen laba riil melalui proksi arus kas operasi. Variabel kontrol LEV mempunyai nilai thitung sebesar 4.513 dengan tingkat signifikan sebesar $0.000<0.01$. Hal ini berarti bahwa variabel kontrol LEV berpengaruh terhadap manajemen laba riil melalui proksi arus kas operasi. Variabel kontrol ROA mempunyai nilai thitung sebesar 12.829 dengan tingkat signifikan sebesar $0.000<$ 0.01. Hal ini berarti bahwa variabel kontrol ROA berpengaruh terhadap manajemen laba riil melalui proksi arus kas operasi.

\section{Model Persamaan 3 (ABN_PROD)}

Adjusted $R$ Square sebesar 0,167 atau 16,7\%, hal ini berarti bahwa variabel manajemen laba riil melalui proksi biaya produksi (ABN_PROD) dapat dijelaskan oleh adopsi IFRS sebagai variabel independen dan SIZE, LEV, ROA sebagai variabel kontrol. Sisanya sebesar $83,3 \%$ variabel manajemen laba riil melalui proksi biaya produksi (ABN_PROD) dapat dijelaskan oleh variabel lain.

Nilai Fhitung sebesar 13,589 dengan tingkat signifikan $0,000(<0,01)$. Hal ini berarti bahwa variabel independen dan variabel kontrol secara bersama-sama berpengaruh secara signifikan terhadap variabel dependen yaitu manajemen laba riil melalui proksi biaya produksi (ABN_PROD).

Variabel kontrol SIZE mempunyai nilai thitung sebesar -1.898 dengan tingkat signifikan sebesar $0.059<0.1$. Hal ini berarti bahwa variabel kontrol SIZE berpengaruh terhadap manajemen laba riil melalui proksi biaya produksi. Variabel kontrol LEV mempunyai nilai thitung sebesar 0.408 dengan tingkat signifikan sebesar $0.684>0.01$, 0.05 dan 0.1 . Hal ini berarti bahwa variabel kontrol LEV tidak berpengaruh terhadap manajemen laba riil melalui proksi biaya produksi. Variabel kontrol ROA mempunyai nilai thitung sebesar 7.067 dengan tingkat signifikan sebesar $0.000<0.01$. Hal ini berarti bahwa variabel kontrol ROA berpengaruh terhadap manajemen laba riil melalui proksi biaya produksi.

\section{Model Persamaan 4 (ABN_DISEXP)}

Adjusted $R$ Square sebesar 0,092 atau 9,2\%, hal ini berarti bahwa variabel manajemen laba riil melalui proksi biaya diskresioner (ABN_DISEXP) dapat dijelaskan oleh adopsi IFRS sebagai variabel independen dan SIZE, LEV, ROA sebagai variabel kontrol. Sisanya sebesar 90,8\% variabel manajemen laba riil melalui proksi biaya diskresioner (ABN_DISEXP) dapat dijelaskan oleh variabel lain.

Nilai Fhitung sebesar 7,395 dengan tingkat signifikan 0,000 $(<0,01)$. Hal ini berarti bahwa variabel independen dan variabel kontrol secara bersama-sama berpengaruh secara signifikan terhadap variabel dependen yaitu manajemen laba riil melalui proksi biaya diskresioner (ABN_DISEXP).

Variabel kontrol SIZE mempunyai nilai thitung sebesar -0.234 dengan tingkat signifikan sebesar $0.815>0.01,0.05$ dan 0.1 . Hal ini berarti bahwa variabel kontrol SIZE tidak berpengaruh terhadap manajemen laba riil melalui proksi biaya diskresioner. Variabel kontrol LEV mempunyai nilai thitung sebesar -2.309 dengan tingkat signifikan sebesar $0.022<0.05$. Hal ini berarti bahwa variabel kontrol LEV berpengaruh terhadap manajemen laba riil melalui proksi biaya diskresioner. Variabel kontrol ROA mempunyai nilai thitung sebesar 4.226 dengan tingkat signifikan sebesar $0.000<0.01$. Hal ini berarti bahwa variabel kontrol ROA berpengaruh terhadap manajemen laba riil melalui proksi biaya diskresioner.

\section{Pembahasan Hasil Hipotesis}

\section{Pengaruh Adopsi IFRS terhadap Manajemen} Laba Akrual

Berdasarkan tabel 4.2 dari model persamaan 1 (DA), variabel independen adopsi IFRS mempunyai nilai thitung sebesar -3.339 dengan tingkat signifikan sebesar $0.001<0.01$ dan nilai koefisien regresi $(\beta)$ menunjukkan arah negatif. Hal ini disimpulkan bahwa adopsi IFRS berpengaruh negatif terhadap manajemen laba akrual, sehingga

\section{H1 diterima.}

Hasil dari analisis regresi linier berganda pada model 1 (DA) mengkonfirmasi dari hasil uji statistik deskriptif yang menunjukkan bahwa nilai rata- rata pada tahal awal adopsi IFRS sebesar 0.061, sedangkan nilai rata-rata pada tahap lanjut adopsi IFRS sebesar 0.020. Hasil tersebut mengindikasikan bahwa tingkat manajemen laba akrual mengalami penurunan pada tahap lanjut adopsi IFRS di Indonesia, 
dengan nilai rata-rata lebih kecil dibandingkan dengan nilai rata- rata pada saat tahap awal adopsi IFRS.

Hasil tersebut sesuai dengan pernyataan hipotesis 1, karena standar IFRS berbasis prinsip memberikan keunggulan dalam hal memungkinkan manajer memilih perlakuan akuntansi yang merefleksikan transaksi atau kejadian ekonomi yang mendasarinya. Standar IFRS berbasis prinsip, juga lebih pada penggunaan nilai wajar, dan pengungkapan yang lebih banyak dan rinci, sehingga diterapkannya standar berbasis IFRS salah satunya adalah dapat menurunkan tingkat manajemen laba melalui discretionary accrual (Cahyati, 2011).

Hasil penelitian ini mendukung penelitian yang dilakukan oleh Barth, et al.,(2008), Ismail, et al., (2013), dan Qomariah (2013).

2. Pengaruh Adopsi IFRS terhadap Manajemen Laba Riil melalui Proksi Arus Kas Operasi, Biaya Produksi, dan Biaya Diskresioner

Berdasarkan tabel 4.2 dari model persamaan 2 (ABN_CFO), variabel independen IFRS mempunyai nilai thitung sebesar -0.045 dengan tingkat signifikan sebesar $0.964>0.01,0.05$ dan 0.1 dengan nilai koefisien regresi $(\beta)$ menunjukkan arah negatif. Hal ini berarti bahwa secara statistik adopsi IFRS tidak berpengaruh terhadap manajemen laba riil melalui proksi arus kas operasi, sehingga $\mathbf{H} 2$ a ditolak.

Dari hasil uji statistik deskriptif terlihat bahwa nilai rata-rata pada tahal awal adopsi IFRS sebesar 0.000 , sedangkan nilai rata-rata pada tahap lanjut adopsi IFRS sebesar 0.000. Hasil tersebut mengindikasikan bahwa, tingkat manajemen laba riil melalui proksi arus kas operasi memiliki nilai rata-rata relatif sama pada tahap awal adopsi IFRS dan pada tahap lanjut adopsi IFRS.

Berdasarkan tabel 4.2 dari model persamaan 3 (ABN_PROD), variabel independen IFRS mempunyai nilai thitung sebesar 0.172 dengan tingkat signifikan sebesar $0.863>0.01,0.05$ dan 0.1 dengan nilai koefisien regresi $(\beta)$ menunjukkan arah positif. Hal ini berarti bahwa secara statistik adopsi IFRS tidak berpengaruh terhadap manajemen laba riil melalui proksi biaya produksi, sehingga $\mathbf{H} \mathbf{2 b}$ ditolak.

Dari hasil uji statistik deskriptif terlihat bahwa nilai rata-rata pada tahap awal adopsi IFRS -0.002 sedangkan nilai rata-rata pada tahap lanjut adopsi IFRS sebesar 0,000. Hasil tersebut mengindikasikan bahwa tingkat manajemen laba riil melalui proksi biaya produksi abnormal mengalami kenaikan sangat kecil pada tahap lanjut adopsi IFRS.

Berdasarkan tabel 4.2 dari model persamaan 4 (ABN_DISEXP), variabel independen IFRS mempunyai nilai thitung sebesar -0.004 dengan tingkat signifikan sebesar $0.997>0.01,0.05$ dan 0.1 dengan nilai koefisien regresi $(\beta)$ menunjukkan arah negatif. Hal ini berarti bahwa secara statistik adopsi IFRS tidak berpengaruh terhadap manajemen laba riil melalui proksi biaya diskresioner, sehingga $\mathbf{H} 2 \mathrm{c}$ ditolak.

Dari hasil uji statistik deskriptif terlihat bahwa nilai rata-rata pada tahap awal adopsi IFRS sebesar 0.000 , sedangkan pada tahap lanjut adopsi IFRS 0,000. Hasil tersebut mengindikasikan bahwa tingkat manajemen laba riil melalui proksi biaya diskresioner memiliki nilai rata-rata relatif sama pada tahap awal adopsi IFRS dan pada tahap lanjut adopsi IFRS.

Hasil ini tidak sesuai dari semua pernyataan hipotesis 2a, 2b, dan 2c disebabkan karena IFRS adalah standar yang mengatur pengukuran, pengakuan dan pelaporan transaksi bisnis, seperti halnya penggunaan nilai wajar (fair value) dalam setiap melalukan transaksi dan mengharuskan melalukan pengungkapan laporan keuangan secara rinci sesuai dengan transaksi yang terjadi. Oleh karena itu, IFRS bukan standar yang mempengaruhi manajer dalam melakukan manajemen laba melalui aktivitas riil bisnis perusahaan secara langsung (Senjani, 2013).

Selain itu, terdapat dugaan lain bahwa investor maupun auditor tidak mampu mendeteksi adanya manajemen laba riil yang dilakukan perusahaan dikarenakan metode estimasi manajemen laba riil yang digunakan terbilang cukup canggih (Febrininta dan Siregar, 2014). Hasil penelitian ini mendukung penelitian yang dilakukan oleh Doukakis (2014) dan Senjani (2013).

\section{SIMPULAN}

Berdasarkan hasil pengujian dan analisis hasil penelitian, maka dapat ditarik simpulan sebagai berikut:

1) Hasil pengujian untuk manajemen laba akrual H1 menunjukkan bahwa adopsi IFRS berpengaruh negatif terhadap manajemen laba akrual.

2) Hasil pengujian untuk manajemen laba riil $\mathrm{H} 2 \mathrm{a}, \mathrm{H} 2 \mathrm{~b}$, dan $\mathrm{H} 2 \mathrm{c}$ menunjukkan bahwa adopsi IFRS tidak berpengaruh terhadap manajemen laba riil melalui proksi arus kas operasi, biaya produksi, dan biaya diskresioner. 
3) Hasil dari keseluruhan pengujian hipotesis dapat disimpulkan, setelah perusahaan mengadopsi IFRS masih belum cukup mampu meningkatkan kualitas laporan keuangan secara keseluruhan dengan cara mengurangi tindakan manajemen laba khususnya tindakan manajemen laba melalui aktivitas riil bisnis perusahaan. Sedangkan untuk manajemen laba akrual terjadi penurunan setalah perusahaan mengadopsi IFRS. Dari situlah diharapkan standar IFRS yang berlaku untuk kedepannya dapat digunakan dan diterapkan oleh perusahaan sebagaimana mestinya aturan yang sudah ada guna mengurangi masalah akuntansi yang terjadi dan mengurangi tindakan manajemen laba melalui discretionary accruals maupun melalui aktivitas riil bisnis perusahaan.

\section{SARAN}

Berdasarkan hasil penelitian, pembahasan dan simpulan makasaran untuk penelitian selanjutnya yaitu:

1) Untuk model proksi manajemen laba akrual disarankan untuk penelitian selanjutnya menggunakan model proksi yang berbeda seperti model manajemen laba akrual yang digunakan oleh Stubben (2010), karena model ini masih terbilang sedikit dipakai untuk mendeteksi manajemen laba akrual.

2) Penelitian selanjutnya dapat memperpanjang periode pengamatan dan mengklasifikasi antara perusahaan yang belum mengadopsi IFRS secara full adoption dengan perusahaan yang telah mengadopsi IFRS secara full adoption.

3) Menambahkan variabel kontrol yang masih banyak menjadi determinan dari manajemen laba, seperti kualitas audit, growth dan lainnya agar memperoleh gambaran variabel lain yang dapat mempengaruhi manajemen laba.

\section{REFERENCES}

Agmarina, Meiza. 2011. Dampak Manipulasi Aktivitas Riil Melalui Arus Kas Kegiatan Operasi Terhadap Kinerja Pasar. Skripsi. Semarang: Fakutas Ekonomi Universitas Diponegoro.

Ahmar, Nurmala., dkk. 2016. Model Manajemen Laba Akrual dan Riil Berbasis Implementasi International Financial Reporting Standards.
Jurnal Akuntansi dan Investasi, Vol.10: 79-92

Armando, E., dan Farahmita, A. 2012. Manajemen Laba Melalui Akrual Dan Aktivitas Riil Di Sekitar Penawaran Saham Tambahan Dan Pengaruhnya Terhadap Kinerja Perusahaan: Studi Pada Perusahaan Yang Terdaftar Di Bursa Efek Indonesia Tahun 2001-2007. Simposium Nasional Akuntansi $\mathrm{XV}$, Banjarmasin

Barth, M.E,. et al. 2008. International Accounting Standards and Accounting Quality. Journal of Accounting Research. Vol.46: 467498

Brigham, Eugene F. dan Houston, J.F. 2001. Manajemen Keuangan Buku II. Edisi Delapan. Jakarta: Erlangga

Cahyati, Ari Dewi. 2011. Peluang Manajemen Laba Pasca Konvergensi IFRS: Sebuah Tinjauan Teoritis dan Empiris. JRAK, Vol.2

Dechow, Patricia M, et al. 1995. Detecting Earning Management. The Accounting Review, Vol. 70: 193-225

Doukakis, L.C. 2014. The Effect of Mandatory IFRS Adoption on Real and Accrual-Based Earnings Management Activities. HEC Lausanne, University of Lausanne, Switzerland. Journal of Accounting and Public Policy, Vol.33: 551-572.

Febrininta, Cut N., dan Siregar, Sylvia V. 2014. Manajemen Laba Akrual Manajemen Laba Riil, dan Biaya Modal. Jurnal Akuntansi Multiparadigma, Vol.5: 345-000.

Handayani, Y.P. 2014. Analisis Perbedaan Manajemen Laba Sebelum dan Sesudah Penerapan Standar Akuntansi Keuangan (Konvergensi IFRS). Skripsi. Padang: Fakultas Ekonomi Universitas Negeri Padang.

Iranto, P. 2014. Pengaruh Konvergensi International Financial ReportingStandard (IFRS) Terhadap Manajemen Laba Akrual dan Riil. Skripsi. Semarang: Fakultas Ekonomika dan Bisnis Universitas Diponegoro.

Ismail., et al. 2013. Earnings Quality and the Adoption of IFRS-Based Accounting Standards Evidence from an Emerging Market. Asian Review of Accounting, Vol.21: 53-73.

Jensen, Michael C and Meckling, William H. 1976. Theory of the Firm: Managerial Behavior, Agency Costs and Ownership Structure. Journal of Financial Economics, Vol.3: 305-360.

Limanto, Danny dan Fanani, Zawnal. 2014. Do IFRS Adoption, Firm Size, And Firm Leverage Influence Earnings Management? Evidence From Manufacturing Firm Listed In 